\title{
ARSENIC IN WATER AND SEDIMENT IN THE IRON QUADRANGLE, STATE OF MINAS GERAIS, BRAZIL
}

\author{
RICARDO PEROBELLI BORBA ${ }^{1}$, BERNARDINO RIBEIRO FIGUEIREDO ${ }^{2}$, BARRY RAWLINS $^{3}$ \\ AND JORG MATSCHULLAT ${ }^{4}$
}

\begin{abstract}
Since the end of 17th century, the Iron Quadrangle in the State of Minas Gerais has been known as one of the most famous gold producing regions in Brazil. Gold was initially produced from alluvial placers and oxidation zones and, finally from primary ores in modern times. Total gold production must have exceeded 13001 in all history. Only in the very famous Morro Velho mine around 600-t gold has been produced since 1834. The gold ore is rich in arsenic with the As/Au ratios ranging from 300 to 3000 among the several deposits deposits. The arsenic in rocks and ores (pyrite, pyrrhotite and arsenopyrite) undergo oxidation during the weathering processes and part of the arsenic is naturally liberated into the environment. Since the tailings produced in the past were discharged directly into drainage until 1980 , the amount of arsenic that entered the drainage systems must have exceeded 3900001 in the whole region. In the Iron Quadrangle region, the highest arsenic concentrations in water and sediment occur near the mining areas where the river sediments were contaminated by tailing discharge since colonial times. In surface drainage water, the dissolved arsenic concentration ranges from $<2$ to $>160 \mathrm{mg} / \mathrm{L}$, and from $<20$ to $>2830 \mathrm{mg} / \mathrm{kg}$ in the stream sediments. Although the present mine operations do not contribute significantly to contamination of the rivers, there are a potential risk for arsenic hazard in some areas induced by, for instance, dispersion of old tailings by flooding, occupation of polluted soils and consumption of contaminated surface and underground water.

Keywords: arsenic, water, groundwater, sediment, tailings, contamination, gold mining, arsenopyrite, Iron Quadrangle, Minas Gerais, Brazil
\end{abstract}

INTRODUCTION Occupying the southeast portion of the Craton do São Francisco, the Iron Quadrangle encompasses four main lithostratigraphic units: granite-gneiss metamorphic complexes, the Archean greenstone belt sequence, called Rio das Velhas Supergroup, Paleoproterozoic metasediments and metavulcanics of the Minas Supergroup, and metasediments of the Itacolomi Group (Dorr 1969). The main gold deposits are found along shear zones that cut rocks of the Nova Lima group, base of the Rio das Velhas Supergroup. Gold deposits from Nova Lima and Santa Barbara, Morro Velho, Raposos, Cuiaba and São Bento districts are mainly associated with pyrite, pyrrhotite and arsenopyrite-bearing banded iron formations (Vieira 1988, Vieira 1991, Ribeiro-Rodrigues 1997). In the Ouro PretoMariana district, the Passagem de Mariana deposit is located close to the contact between the rocks of the Nova Lima Group and the Minas Supergroup. The gold mining, very rich in arsenopyrite, occurs in quartz and carbonate veins, hosted in BIF, tourmalinite, phyllite and quartzite (Vial 1988, Oliveira 1998).

The presence of arsenic in primary gold ore in the Iron Quadrangle is therefore conspicuous either as discrete minerals, such as arsenopyrite and loellingite, or as the impurity in the remaining sulfides, mainly in pyrite. The ratio As/Au in these ores can vary considerably in the interval of 300 to 3.000 . Geochemical studies focusing on arsenic in the Iron Quadrangle have already been carried out in the past, oriented towards mineral prospecting, including the one carried out by the Research Company of Mineral Resources (Oliveira et al. 1979), as well as for environmental evaluation (Eleuterio 1997) and human monitoring (Matschullat et al. 2000).

This paper aims to contribute to better understand the geochemical distribution of arsenic in sediments and surface water, and discuss its probable sources and potential risks of environmental contamination in the three most important gold production regions in the Iron Quadrangle (Fig. 1 a-e): the Nova Lima district (Das Velhas river basin), the district of Ouro Preto-Mariana (Carmo river basin) and the Santa Barbara district (Conceição river basin).

\section{SAMPLE METHODOLOGIES AND ANALYTICAL}

TECHNIQUES The materials studied here consisted of samples of water and sediment sampled in April 1997, June 1997 and April 1998 (Fig. 1 a-e). In addition, samples of oxidized ores, tailings and underground water were studied with a view to support the discussions on the sources of contamination and environmental risks.

In each sampling site $\mathrm{pH}$-values, Eh, conductivity, DO, turbidity, and the water temperature were measured electrochemically in situ. Filtered $(0,45 \mathrm{~mm})$ and non-filtered water samples were collected in the Das Velhas and Do Carmo rivers. The total alkalinity of the bicarbonate of the water samples was determined by titration briefly after sampling. Filtered water samples were analyzed by ICP-AES (cations) and by ion chromatography (anions) in the British Geological Survey laboratories, and the concentration of dissolved arsenic was determined by atomic fluorescence in the same lab. The concentrations of total arsenic in samples of unfiltered water were determined by AAS with a coupled hydride generator (HG-AAS) in the Institute of Geoscience at Unicamp University.

The sediment samples were dried naturally and passed through nylon sieves. Only the fraction lower than $63 \mathrm{~mm}$ of the samples was analyzed by ICP-AES in GEOSOL Lab after partial digestion (HC1 + $\mathrm{HNO}_{3} ; 1: 3$ ). This fraction of the sediments was also analyzed by XRD at Department of Geology (UFOP).

In addition, slides and polished sections of samples of primary and oxidized ore were examined under the petrographic microscope and the scanning electronic microscope of the Unicamp Institute of Geoscience. Other random samples of soil, residues and underground water were analyzed by the methods described above.

RESULTS OF HYDROGEOCHEMISTRY AND GEOCHEMISTRY OF SEDIMENTS Velhas River basin In the Rio das Velhas basin (Fig. $1 \mathrm{a}-\mathrm{c}$ ) the water are neutral and oxidized with minimum $\mathrm{pH}$ of 6.5 (EGA 1) and Eh varying between $115 \mathrm{mV}$ (EGA 1) and $230 \mathrm{mV}$ (ERV 1). The conductivity varied between 70 and $150 \mathrm{mS} / \mathrm{cm}$ in Rio das Velhas and in the Ribeirao do Cardoso (EGA 1 and ERV 1), and went up to $1.400 \mathrm{mS} / \mathrm{cm}$ (ERQ 1) in the Ribeirao do Queiros. In the water samples, the anion $\mathrm{HCO}_{3}$ predominates, followed by $\mathrm{SO}_{4}{ }^{2}$ however, in the Ribeirao do Queirós (ERQ 1), the opposite situation occurs with $\mathrm{SO}_{4}{ }^{2}>\mathrm{HCO}_{3}{ }^{-}$. In these samples, $\mathrm{Ca}$ is the predominant cation, followed by $\mathrm{Mg}, \mathrm{Na}$ and $\mathrm{K}$. Among the analyzed trace elements, only As exceeds the limit of 50 $\mathrm{mg} / \mathrm{L}$ established by CONAMA (1986) for water courses with aquatic life, reaching $160 \mathrm{mg} / \mathrm{L}$ in the Ribeirao do Cardoso (EGA 1). In samples of unfiltered water, total As contents were two to ten times higher than the concentration of dissolved As of the filtered samples, e.g., for Ribeirao do Cardoso, a content of $1.445 \mathrm{mg} / \mathrm{L}$ was found for total As.

Sediments of the Rio das Velhas basin showed high As concentration, exceeding $1,000 \mathrm{mg} / \mathrm{kg}$ (EGAl and ERQ1), Cd (18 mg/ $\mathrm{kg}$, EGA IS), Pb (38 mg/kg, ERV1) and Zn (193 mg/kg, ECB1). In these sediment samples the minerals kaolinite, illite and goethite were identified through X-ray diffractometry.

Carmo River basin The water samples from Rio do Carmo (Fig. Id) presented oxidizing $(\mathrm{Eh}=170-240 \mathrm{mV})$ and neutral characteristic, with $\mathrm{pH}>7.2$. The conductivity in the water samples varied from 120 $\mathrm{mS} / \mathrm{cm}$ (ERC7) up to $360 \mathrm{mS} / \mathrm{cm}$ (ERC1). At these water sampling stations the main cation were $\mathrm{Ca}$ or $\mathrm{Na}$ whereas the main anions were $\mathrm{HCO}_{3}^{-}$and $\mathrm{SO}_{4}{ }^{2}$.

Oxidizing waters from the Passagem de Mariana gold mine (EPM1) and from the lateral mine adit (EPM2), with Eh between ISO$250 \mathrm{mV}$, presented $\mathrm{pH}$ values of 7.8-8.3 and 4.8-7.7 respectively. The conductivity of these samples oscillated between $230-310 \mathrm{mS} / \mathrm{cm}$ in

1 - Institute de Geociências, Unicamp, CP 6152 - Cep 13.083-970 - Campinas - São Paulo Brasil; borba@ige.unicamp.br

2 - Institute de Geociências, Unicamp, CP 6152 - Cep 13.083-970 - Campinas - São Paulo Brasil; berna@ige.unicamp.br

3 - British Geological Survey, Key worth, Nottingham -UK- NG12 5GG,

4 - Terhnicnl University of Freiberg, Brennhausgasse 14, D-09599, Freiberg, Germany; matschullat@ioez.tu-freiberg.de 


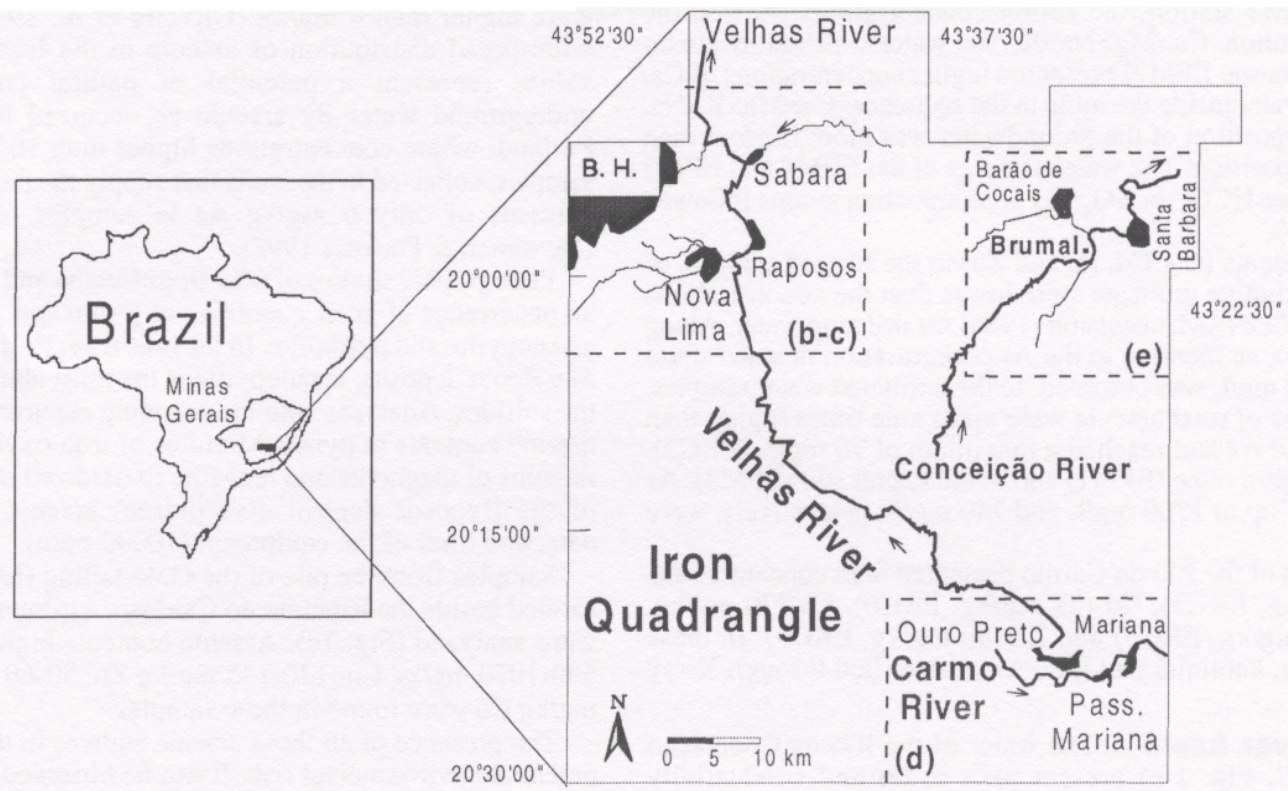

(a)

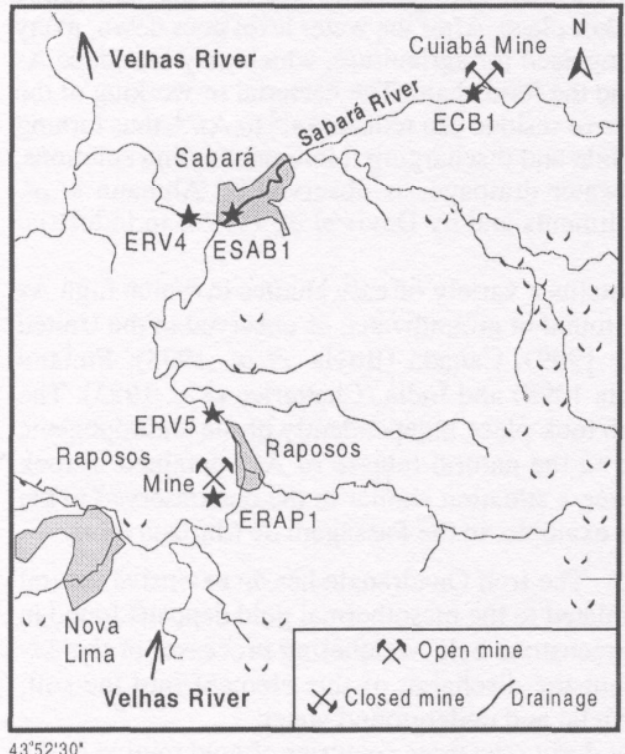

(b)

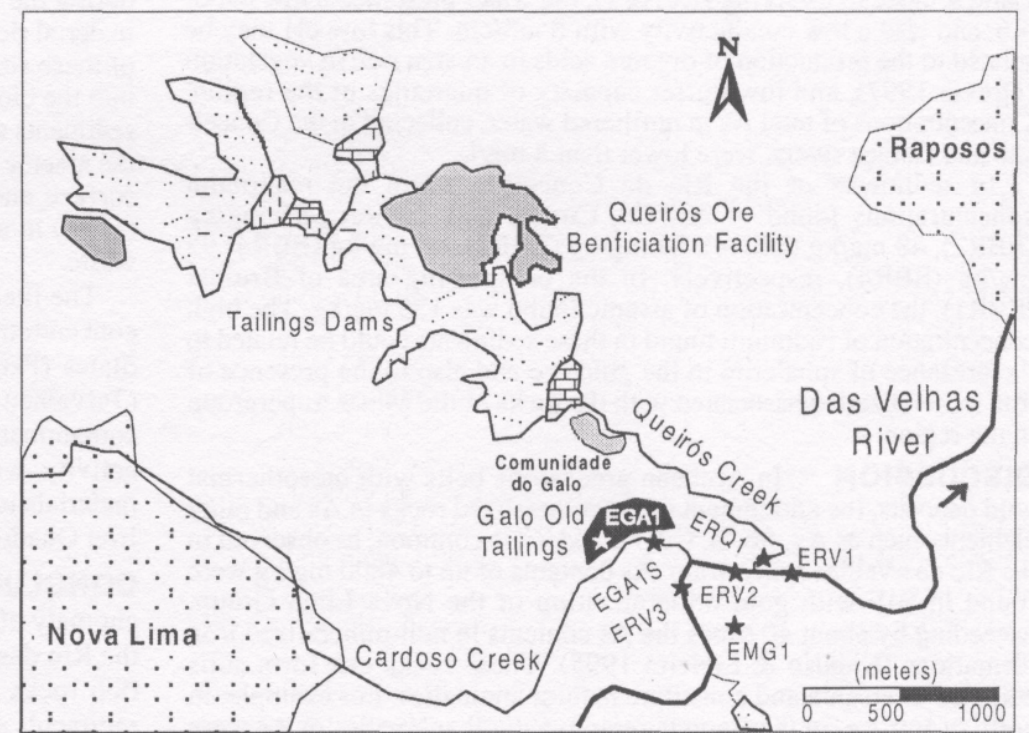

(c)

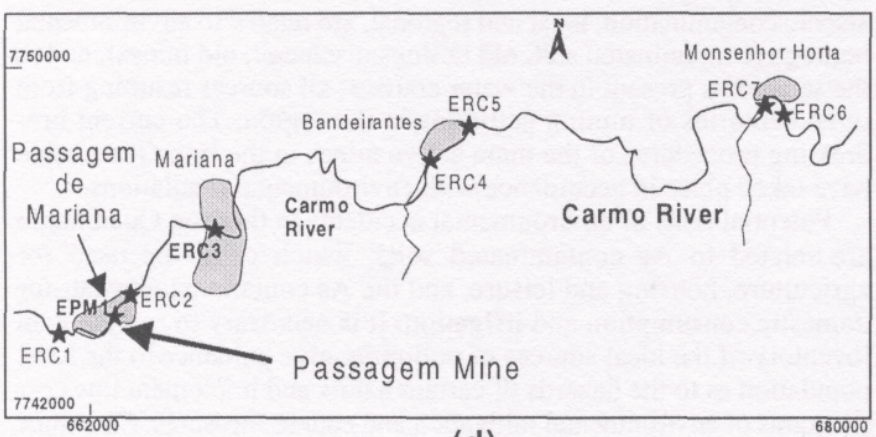

(d)

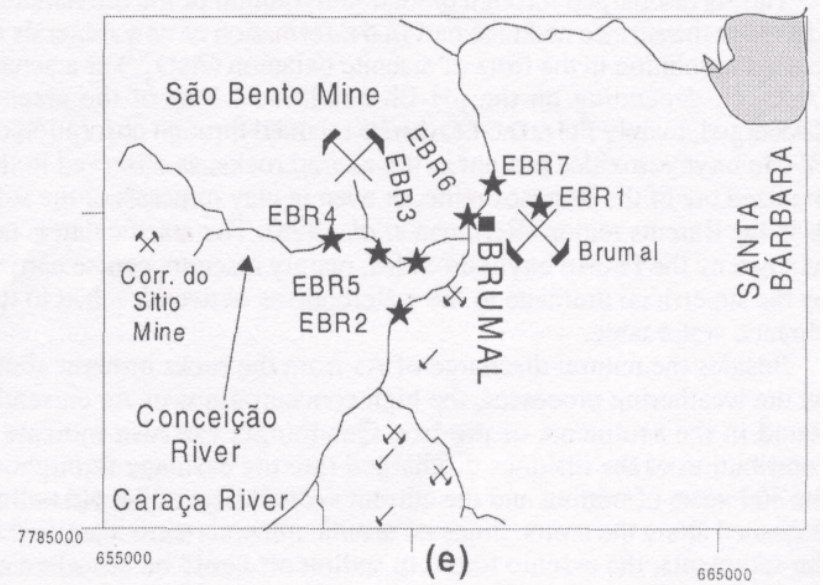

Figure 1 - Location map of samling stations in the studied area: (a) Velhas river basin, (d) Carmo river basin, (e) Conceição river basin. In (b) and (c) details of the Velhas river basin showing the Cuiabá and Raposos mines and Queiroz Ore Dressing Facility. 
the EPM1 station, and $130-430 \mathrm{mS} / \mathrm{cm}$ in the mine adit (EPM2) as well. At the EPM1 station, the cation concentrations showed the following distribution: $\mathrm{Ca}>\mathrm{Mg}>\mathrm{Na}>\mathrm{K}$. The water expelled by the lateral mine adit (station EPM2) presented higher concentrations of $\mathrm{Ca}$, $\mathrm{Mg}$ and $\mathrm{K}$ than water inside the mine in the sequence: $\mathrm{Ca}>\mathrm{Mg}>\mathrm{K}>\mathrm{Na}$. The anionic composition of the groundwater was more random than the cationic composition. The water samples of the EPM1 and EPM2 stations have either $\mathrm{HCO}_{3}^{-}$or $\mathrm{SO}_{4}^{2-}$ as predominating anions followed by $\mathrm{NO}_{3}{ }^{-}$and $\mathrm{Cl}^{-}$.

The metal contents $(\mathrm{Cu}, \mathrm{Cd}, \mathrm{Pb}$ and $\mathrm{Zn})$ in the filtered samples of surface water and mine drainage were lower than the concentrations permitted by the CONAMA decision (1986) for drinking water. Along the Rio do Carmo, an increase in the As concentration in water up to a maximum of $30 \mathrm{mg} / \mathrm{L}$ was observed. In the unfiltered water samples, the concentrations of total arsenic were up to nine times higher than those of dissolved As and reached a maximum of $70 \mathrm{mg} / \mathrm{L}$ (ERC3). Within the Passagem mine (EPM1) and in the lateral adit (EPM2), As concentrations of up to $1700 \mathrm{mg} / \mathrm{L}$ and $740 \mathrm{mg} / \mathrm{L}$, respectively, were found.

The sediments of the Rio do Carmo presented high concentrations of As $(860 \mathrm{mg} / \mathrm{kg}$, ERC3), Cd (37 mg/kg, ERC6), Cu (70 mg/kg, ERC5), $\mathrm{Pb}(45 \mathrm{mg} / \mathrm{kg}$, ERC5) and $\mathrm{Zn}(80 \mathrm{mg} / \mathrm{kg}$, ERC5). In these samples, goethite, kaolinite and illite were identified through X-ray diffractometry.

Conceição River basin The water of the Rio da Conceição (stations EBR3-7, Fig. 1-e) present $\mathrm{pH}>6$, Eh and conductivity between $230-280 \mathrm{mV}$ and $70-110 \mathrm{mS} / \mathrm{cm}$, respectively. In Rio do Caraça, close to its spring (ECARl), the water presented a low $\mathrm{pH}$ of 4.6 , and also a low conductivity with $8 \mathrm{mS} / \mathrm{cm}$. This low $\mathrm{pH}$ may be related to the production of organic acids in an area rich in vegetation (Drever 1997), and low buffer capacity of quartzites of the region. Concentrations of total As in unfiltered water, collected in the Conceição and Caraça rivers, were lower than $8 \mathrm{mg} / \mathrm{L}$.

In sediments of the Rio da Conceição basin the maximum concentrations found of $\mathrm{As}, \mathrm{Cd}, \mathrm{Cu}, \mathrm{Pb}$ and $\mathrm{Zn}$ were $85 \mathrm{mg} / \mathrm{kg}$ (EBR2), $48 \mathrm{mg} / \mathrm{kg}$ (EBR4), $54 \mathrm{mg} / \mathrm{kg}$ (EBR2), $48 \mathrm{mg} / \mathrm{kg}$ (EBR4) 95 $\mathrm{mg} / \mathrm{kg}$ (EBR4), respectively. In the prospecting area of Brumal (EBR1), the concentration of arsenic found was $135 \mathrm{mg} / \mathrm{kg}$. The high concentration of cadmium found in these sediments could be related to the presence of sphalerite in the gold ore and also to the presence of iron mineralization associated with the rocks of the Minas Supergroup in the region.

DISCUSSION In Archean greenstone belts with mesothermal gold deposits, the enrichment of the mineralized rocks in As and other elements such as $\mathrm{Ag}, \mathrm{Sb}, \mathrm{B}, \mathrm{Cu}, \mathrm{Pb}$ and $\mathrm{Zn}$ is common, as observed in the Rio das Velhas supergroup. As contents of up to $4800 \mathrm{mg} / \mathrm{kg}$ were found in BIF with gold mineralization of the Nova Lima Group, exceeding by about 40 times the As contents in non-mineralized iron formations (Raposo \& Ladeira 1995). These rocks can form soils enriched in arsenic and constitute natural anomalies. For example, in north of Europe, in the Barents region, natural anomalies of As were identified in soil close to greenstone belt gold mineralization (Reimann etal 1998).

The As discharged through oxidation/hydration of the ore minerals can reach the surface and take part in the formation of new minerals or carried in solution in the form of arsenite oxianion $\left(\mathrm{AsO}_{3}{ }^{3}\right)$ or arsenate $\left(\mathrm{AsO}_{4}^{-3}\right)$, depending on the $\mathrm{pH}-\mathrm{Eh}$ conditions. Part of the arsenic discharged, mainly the arsenate, can be retained through absorption on Fe-Mn oxyhydroxides present in the altered rocks, as observed in the oxidized ore of the Raposos mine, or even in clay minerals of the soil, as in the Barents region (Reimann et al. 1998). The arsenic that is not retained by the Fe-Mn oxyhydroxides, mainly arsenite, can be carried by the superficial drainage to the watercourses or even leached to the phreatic water table.

Besides the natural discharge of As from the rocks brought about by the weathering processes, the high concentrations of As currently found in the sediments of the Iron Quadrangle can also indicate a contribution of the residues discharged into the drainage throughout the 300 years of mining and the current re-workings of the old tailing deposited along the rivers. Since no arsenic minerals were identified in the sediments, the arsenic found in sediments could be adsorbed on goethite, kaolinite and illite, minerals that are good scavengers of dissolved arsenic anions.

The highest concentrations of arsenic in the sediments of the Iron Quadrangle were found close to the big mines in the districts of Nova Lima, Passagem de Mariana and Santa Barbara. However, even in regions without mines and prospecting, As concentrations in sediments were higher than $8 \mathrm{mg} / \mathrm{kg}$ (Oliveira et al. 1979), which reflects a widespread distribution of arsenic in the Iron Quadrangle. These values represent a potential of natural contamination of the underground water by arsenic as occurred in certain regions of Finland, where concentrations higher than $10 \mathrm{mg} / \mathrm{L}$ of As in water samples, collected in the wells that supply the population are related to contents of only $6 \mathrm{mg} / \mathrm{kg}$ As in samples of soil and sediment (Tarvainen \& Paukola 1998).

Petrographic studies of ores from Cuiaba and Raposos mines show an occurrence of great quantities of pyrite and, to a lesser degree, of arsenopyrite and pyrrhotite. In the ores from Passagem de Mariana and São Bento deposits, arsenopyrite is the most abundant mineral among the sulfides. Analyses with the scanning electron microscope showed arsenic contents in pyrite. Mixtures of iron oxyhydroxides including remains of magnetite and hematite in oxidized rocks from the surface of the Raposos deposit also present arsenic contents above the detection limit of the equipment (10000-ppm).

Samples from the pile of the Galo tailing (EGA1), an old deposit located beside the Ribeirao do Cardoso, a tributary of Rio das Velhas, were analyzed (Fig. Ic). Arsenic contents higher than $5000 \mathrm{mg} / \mathrm{kg}$, $590-1070 \mathrm{mg} / \mathrm{kg} \mathrm{Cu}, 120-145 \mathrm{mg} / \mathrm{kg} \mathrm{Zn}, 50-60 \mathrm{mg} / \mathrm{kg} \mathrm{Pb}$ and $36-40$ $\mathrm{mg} / \mathrm{kg} \mathrm{Cd}$ were found in these samples.

The presence of all these arsenic sources in the region give rise to potential environmental risk. It can be observed, for example, that in the flood basins that form along the rivers of the Iron Quadrangle during the wet season, the deposition of fine sediment and suspended material rich in As takes place. After the water level goes down, many of these sites are being used for agriculture, which may introduce As into the biological and the food chain. The bacterial re-working of the sediments and the pile of residue can reduce $\mathrm{As}^{+5}$ to $\mathrm{As}^{+3}$, thus turning the arsenic more mobile and discharging it into percolating solutions, surface and groundwater drainage, as observed by Ahmann et al. (1994) in anoxic sediments and by Davis et al. (1996) in industrial waste.

The literature contains a variety of case studies in which high As concentrations were found in groundwater, as observed in the United States (Peters et al. 1999), Canada (Boyle et al. 1998), Finland (Tarvainen \& Paukola 1998) and India (Chatterjee et al. 1995). The contamination, which took place independently of the anthropogenic activity, was related to the natural release of As contained in rock materials to the aquifer, a situation similar to the one observed in the Iron Quadrangle, for example, in the Passagem de Mariana mine.

CONCLUSIONS The Iron Quadrangle has an extensive natural anomaly of arsenic related to the mesothermal gold deposits found in the Rio das Velhas greenstone belt. Weathering processes of the Asrich rocks bring about the discharge of this element into the soil, sediments and superficial and underground water.

It is estimated that during the three centuries of gold mining in the Iron Quadrangle, at least 390,000 tons of arsenic was discharged into the drainage system. Currently, the main sources of anthropogenic arsenic contamination, local and regional, are related to environmental heritage (contaminated soil, old tailings discharge, old mines), and to the sediments present in the water courses; all sources resulting from three centuries of mining activities in the region. The current oredressing procedures of the main active mines in the Iron Quadrangle have taken place in accordance with environmental regulations.

Potential risks of environmental accidents in the Iron Quadrangle are related to As contaminated soils, which could be used for agriculture, housing and leisure, and the As contaminated water for domestic consumption and irrigation. It is necessary to carry out an inventory of the local sources of pollution, give guidance to the local population as to the hazards of certain habits and implement low cost programs of environmental mitigation and countermeasures. Care must be taken in relation to the consumption of underground water and of treated surface water, since the toxic effects of arsenic can take many years to become apparent and the conventional treatment of water does not remove the dissolved arsenic.

Acknowledgments To FAPESP (grants \# 97/14446-6, \# 96/ 7839-9 and 95/6401-7) for field, flaboratory and fellowsho supports. To two anonymous referees of RBG for the critical review of the manuscript. 


\section{References}

Ahmann D., Roberts A.L., Krumholz L.R., Morel F.M.M. 1994. Microbe grows by reducing arsenic. Nature, 371: 750.

Boyle D.R., Turner R.J.W., Hall G.E.M. 1998. Anomalous arsenic concentrations in groundwaters of an island community, Bowen Island, British Columbia. Environmental Geochemistry Health, 20(4): 199-212.

Chatterjee A., Das D., Mandal B.K.", Chowdhury T.R., Samanta G., Chakraborti D. 1995. Arsenic in ground water in six districts of West Bengal, India: the biggest arsenic calamity in the world. Part 1: Arsenic species in drinking water and urine of affected people. Analyst, 120: 643-650

CONAMA. 1986. Resolucao CONAMA n ${ }^{\circ}$ 20, de junho de 1986 - Resolução do CONAMA - 1984/86, Brasilia: SEMA, 92p.

Davis A. Ruby M.V., Bloom M., Schoof R. Freeman G., Bergstrom P.O. 1996. Mineralogic constraints on the bioavailability of arsenic in smelter-impacted soils. Mineralogic constraints on the bioavailability of arsenic in smelter-impacted soils.

Environmental Science Technology, 33(2): 392-399.

Dorr II J. V. N. 1969. Physiographic, stratigraphic and structural development of the $Q F$, Brazil. Washington, DNPM/USGS. 109p. (Prof. Paper 641-A).

Drever J.I. 1997. The Geochemistry of Natural Waters - surface and groundwater environments. 3rd ed. New Jersey, Prentice Hall, 438 p..

Eleuterio L 1997. Diagnostico da situacdo ambiental da cabeceira da bacia do rio doce, no âmbito das contaminações par metais pesados em sedimentos de fundo. Depto. de Geologia, Escola de Minas, Universidade Federal de Ouro Preto, Dissertação de mestrado, $163 p$

Matschullat J., Borba R.P., Deschamps E., Figueiredo B.F., Gabrio T., Schwenk M. 2000. Human and environmental contamination in the Iron Quadrangle, Brazil. Applied Geochemistry, 15: 181-190.

Oliveira F. R. 1998. Contribuição ao estudo da geologia estrutural e da gênese do depósito aurifero de Passagem de Mariana-M.G. Campinas,. Inst. de Geociências, Uni-

versidade Estadual de Campinas. Dissertacão de Mestrado, $127 \mathrm{p}$

Oliveira J.J.C., Ribeiro J.H., Souza Oki S., Barros J.R.R. 1979. Projeto Geoquímica do Quadrildtero Ferrifero: Levantamento orientativo e regional, Relatório Final, VI. Belo Horizonte, CPRM, 133p.
Peters S.C., Blum J.D., Klaue B., Karagas.M.R. 1999. Arsenic occurence in New Hampshire drinking water. Environmental Science Technology, 33(9): 1328-1333. aposo F.O. \& Ladeira E. 1995. Padrões de terras-raras de algumas formações ferríferas arqueanas do QF. A Terra em Revista, 1(0): 19-23.

Reimann C., Ayras M., Chekushin V, Bogatyrev I., Boyd R., Caritat P. de, Dutter R., Finne I.E., Halleraker J.H., Jaeger O., Kashulina G., Letho O., Niskavaara H., Pavlov V, Raisanen M.L., Strand T., Volden T. 1998. Environmental Geochemical Atlas of the Central Barents Region. Geological Survey of Norway, $745 \mathrm{p}$.

Ribeiro- Rodrigues L.C. 1998. Gold mineralization in Archean banded iron-formation of the $Q F$, Minas Gerais, Brazil - The Cuiabd Mine. RTWH Aachen, Aachen. Philosophy Thesis, 262p.

Tarvainen T. \& Paukola T. 1998. Use of geochemical databases to delineate risk areas for contaminated groundwater. Journal of Geochemical Exploration, 64:177-184

Vial D. S. 1988. Mina de ouro de Cuiabá, QF, Minas Gerais,. In: Principais Depósitos Minerais do Brasil. Brasilia, DNPM/CVRD,v.3, p. 413-419.

Vieira F.W.R. 1988. Processes epigenéticos de formação dos depósitos auriferos e zonas de alteração hidrotermal do Grupo Nova Lima, Quadrilatero Ferrifero, Minas Gerais. In: alteração hidrotermal do Grupo Nova Lima, Quadrilatero Ferrifero, Minas

Vieira F.W.R. 1991. Textures and processes of hydrotermal alteration and mineralization in the Nova Lima Group, Minas Gerais,Brasil. In E.A.Ladeira (ed.), BRAZIL the Nova Lima Group, Minas Gerais,Brasil.

WHO (1993) Guidelines for drinking water quality. Geneva, World Health Organizarion., $188 \mathrm{p}$.
Contribution IGC-077

Received February 24,2000 Accepted for publication April 29, 2000 